\title{
EVIDENCE OF TIDE POOL USE BY A VIVIPAROUS ELASMOBRANCH AS A PARTURITION SITE
}

\author{
Natascha WOSNICK ${ }^{1 *}$, Rodrigo Moro RIOS ${ }^{2}$, Getulio RINCON ${ }^{3}$, and Jorge Luiz Silva NUNES ${ }^{1}$ \\ ${ }^{1}$ Laboratório de Organismos Aquáticos, Departamento de Oceanografia, Universidade Federal do Maranhão, \\ São Luís, MA, Brazil \\ ${ }^{2}$ Laboratório de Biologia e Ecologia de Vertebrados, Universidade Federal do Paraná, Curitiba, PR, Brazil \\ ${ }^{3}$ Laboratório de Pesca, Centro de Ciências Humanas, Naturais da Saúde e Tecnologia-CCHNST, Universidade \\ Federal do Maranhão, Pinheiro, MA, Brazil
}

Wosnick N., Rios R.M., Rincon G., Nunes J.L.S. 2019. Evidence of tide pool use by a viviparous elasmobranch as a parturition site. Acta Ichthyol. Piscat. 49 (2): 189-193.

\begin{abstract}
Despite the frequent occurrence of elasmobranchs in surf zones, the use of tidal pools by these animals is unknown, with only one incidental observation reported in the literature. Here we present a possible birth observation in a tide pool for the shortnose guitarfish, Zapteryx brevirostris (Müller et Henle, 1841). We discuss this occurrence as it relates to the possible use of this micro-habitat to take advantage of its ecological characteristics during parturition, the moment of extreme vulnerability to viviparous elasmobranchs.
\end{abstract}

Keywords: guitarfish, birth, behaviour, lecithotrophic viviparity

\section{INTRODUCTION}

The shortnose guitarfish, Zapteryx brevirostris (Müller et Henle, 1841) (Family: Rhinobatidae), is a small-sized batoid species, endemic to the South-western Atlantic Ocean, with a mean total length of $50 \mathrm{~cm}$ (Last et al. 2016, Carmo et al. 2018). As a benthic/invertivore inshore species, $Z$. brevirostris can be found on unbound substrate up to $50 \mathrm{~m}$ depth (Bornatowski et al. 2014). This guitarfish exhibits yolk-sac viviparity, a lecithotrophic viviparous reproduction mode, with four to eight neonates per breeding cycle (Batista 1987, 1991, Abilhoa et al. 2007, Colonello et al. 2011).

The reproductive cycle observed for $Z$. brevirostris seems to be influenced by latitudinal marks. Current literature reports two distinct patterns of reproduction along with this species distribution range. In southern Brazil, births are observed in summer (December to March) (Abilhoa et al. 2007), while in south-eastern Brazil and Argentina an opposite pattern is observed with births during winter (June to September) (Batista 1991, Colonello et al. 2011).

The use of tide pools brings several advantages, such as protection from predators and abundant food resources (Metaxas and Scheibling 1993, Cunha et al.2007, CastellanosGalindo and Giraldo 2008). However, given the instability of this microhabitat (i.e., constant abiotic fluctuations), few species can survive, since a set of behavioural and/or morphophysiological traits are necessary to thrive in such environments (Griffiths et al. 2006, Nunes et al. 2011).

Despite the preliminary knowledge regarding natural birth vs. capture-induced abortion in Z. brevirostris, parturition and nursery areas, as well as prepartum behaviour, are unknown for the species. Here, we reported the occurrence of adult females and newborn offspring using a tide pool in south-eastern Brazil. We discussed this observation as it relates to a possible birth event in a tide pool, which to our knowledge, would be the first report of that nature for any elasmobranch species.

\section{MATERIAL AND METHODS}

The observation took place in a warm $\left(>25^{\circ} \mathrm{C}\right)$ and dry day of July 2011. The sea was flat with a very light onshore wind $\left(<10 \mathrm{~km} \cdot \mathrm{h}^{-1}\right)$. During falling tide, opportunistic observations of a sandy-bottom, $30 \mathrm{~cm}$ depth tidal pool at Praia Brava $\left(22^{\circ} 58^{\prime} 58^{\prime \prime} \mathrm{S}, 042^{\circ} 01^{\prime} 19^{\prime \prime} \mathrm{W}\right)$, Arraial do Cabo, Brazil were made (Fig. 1A). The length ( $\sim 50 \mathrm{~m})$ and width $(\sim 20 \mathrm{~m})$ of the site were estimated through satellite images of the region. Upon arrival, the pool was linked to the sea by a thin water layer, which was broken soon after. The water inside the pool $\left(\sim 28^{\circ} \mathrm{C}\right)$ was considerably warmer than the surrounding sea $\left(\sim 23^{\circ} \mathrm{C}\right)$ (Fig. 1B). The observations were made during the waning moon, in a day of small tidal variation $(\sim 1.5 \mathrm{~m})$. 


\section{RESULTS}

Initial coincidental observation was made at 15:30 $\mathrm{h}$ with no sightings (Fig. 1C). At 17:15 h, another observation was made, with two adult females and four neonates being sighted. Total length (TL) of females was estimated at $45.0 \mathrm{~cm}$ and $50.0 \mathrm{~cm}$. Two neonates were also hand captured with an estimated total length of 13.0 and $14.5 \mathrm{~cm}$ (Figs. 2A-2D). The neonates exhibited reduced yolk sac, with about $1 \mathrm{~g}$ content. Such characteristics coupled with the total length of the neonates also indicate birth in the tide pool, rather than a simultaneous entry in the site. One last observation was made at 18:10 $\mathrm{h}$ and the females and neonates could not be found in the tide pool (Fig. 1D).

\section{DISCUSSION}

Tide pools are confined to certain periods of the tidal cycle, being considered a very specific marine environment that can be exploited in different ways by various species of fish due to its microhabitat heterogeneity (Griffiths et al. 2006, Nunes et al. 2011). Among the uses most commonly cited in the literature are a refuge and/or juvenile protection (Metaxas and Scheibling 1993, Cunha et al. 2007), feeding
(Castellanos-Galindo and Giraldo 2008) and spawning (Coelho et al. 2013).

Elasmobranchs have often been reported using intertidal zones, mostly of an unhardened substrate (Vooren and Klippel 2005, Pierce et al. 2011, Tobin et al. 2014). Yet, their occurrence in tide pools is seemed as extremely rare. Up to this moment, only one study reported on an elasmobranch using such an environment (Nunes et al. 2011). Even so, there was only one record of a single juvenile of the smooth butterfly ray, Gymnura micrura (Bloch et Schneider, 1801), in eight years of monitoring in an environment influenced by macrotidal (Nunes et al. 2011). The previous study has reported birth in a captive $Z$. brevirostris, with newborns with a similar body length (Gonzalez 2004) to what we inferred here. Yet, the stay-still behaviour observed in the present report was also described in neonates of this species (Gonzalez 2004), leading us to believe that the animals we observed here were also likely to be neonates. Also, the date of observation was compatible with the period of birth described for the species in the region of south-eastern Brazil (birth in winter) (Batista 1991), another strong evidence that birth occurred spontaneously. Another strong evidence of birth in the tidal pool was the damage to the cloaca and abdominal retraction observed
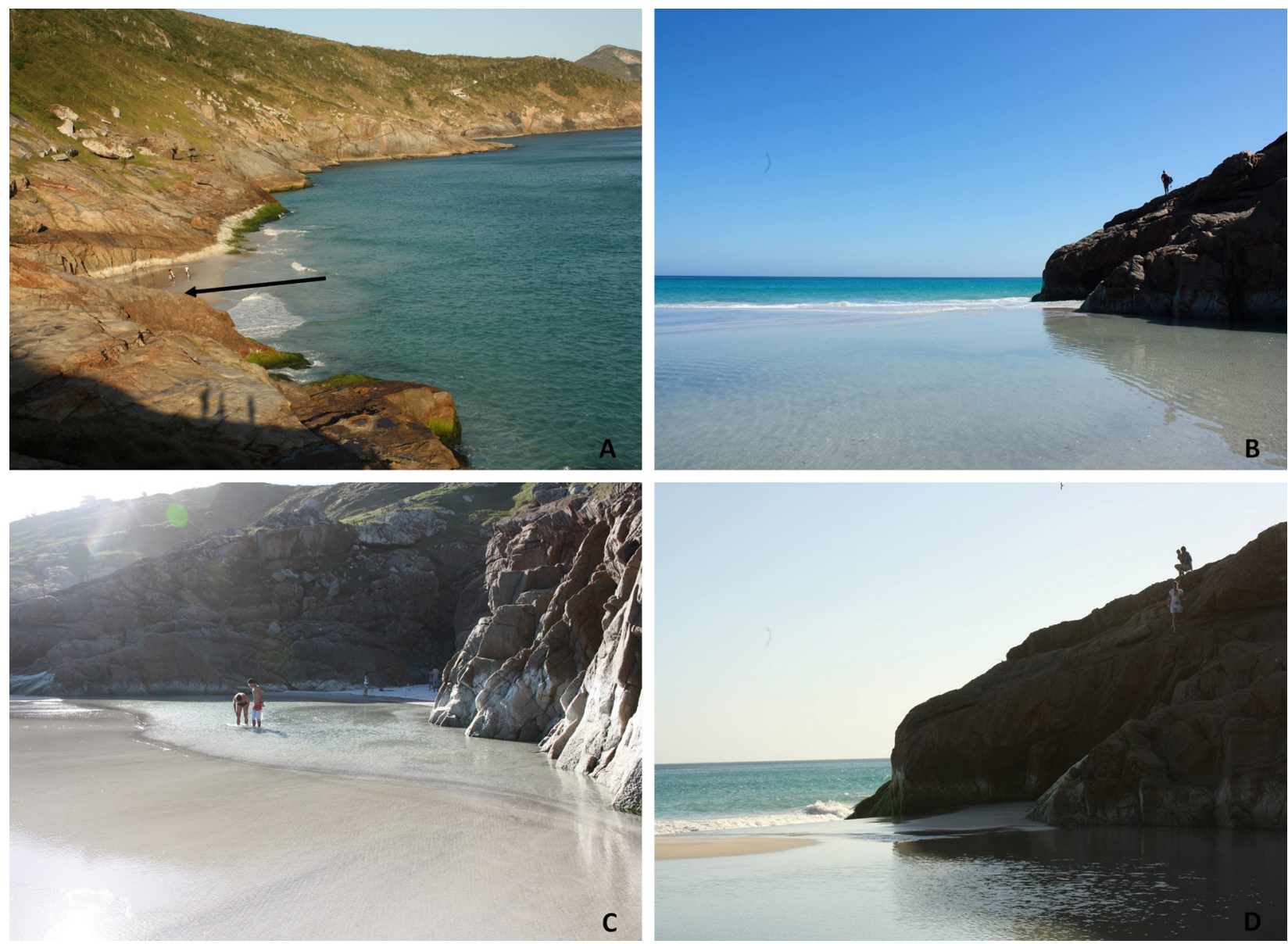

Fig. 1. Dynamics of the tide pool of the presently reported study; (A) rocky shore located in Arraial do Cabo, Rio de Janeiro, Brazil. The black arrow points to the tide pool location; (B) tide pool being formed via connection with the intertidal zone; (C) tide pool during the isolation period; (D) tide pool in the late afternoon, being slowly connected to the intertidal zone 
in one of the females, morphological alterations consistent with parturition in viviparous elasmobranchs (Wosnick et al. 2018).

The animals observed in the present report were found in an area of influence of the Arraial do Cabo upwelling system. Such a phenomenon causes the intrusion of the South Atlantic Central Water (SACW) on the continental shelf (Valentin and Monteiro-Ribas 1993, Guimaraes and Coutinho 1995). This physical process is known for its influence on the local marine structure, as it increases nutrient availability, altering phytoplankton biomass and primary production and as consequence feeding dynamics in the region (Gonzalez-Rodriguez et al. 1992, Carvalho and Gonzalez Rodriguez 2004). Although the record took place outside the upwelling period in the region (late spring and summer), tide pools occur in rocky shores with similar environmental conditions to those observed during this phenomenon and in which the species is found in the coast of Rio de Janeiro. So, it is possible that the use of a tidal pool reported here may be explained by the high physiological plasticity presented by this species.

Zapteryx brevirostris is often observed near the coast and rocky shores (Monteiro-Neto et al. 2008), being commonly targeted in amateur fishing in the region (Batista 1991). During gestation, females stay close to the coast, giving birth in warmer waters and depths of up to $7 \mathrm{~m}$ (Vooren et al. 2005). After birth, neonates spend their first year in the surf zone, being such area characterized as a nursery for Rhinobatidae in general (Vooren et al. 2005).
Despite being classified as marine, the species exhibits strong plasticity, tolerating salinity reduction up to $5 \%$ (Wosnick and Freire 2013). Zapteryx brevirostris can survive to extreme conditions, such as the stress of capture (i.e., being commonly landed alive), and air exposure (i.e., survival capacity for up to six hours out of water) (personal observation). All those characteristics lead us to believe that the use of tidal pools by adults as parturition areas is physiologically possible, but for reasons not yet known, unusual.

During parturition, females and especially neonates with little swimming capacity are likely to be exposed to higher predation risk. Thus, tide pool use could be important to Z. brevirostris reproduction. Further analysis could shed light on the possible benefits of using tide pools for reproduction by quantifying survival and reproductive benefits for females during parturition and for neonates during their first hours of life.

It is also worth considering that the parturition reported here may have been a result of the stress caused by a confinement in a challenging environment. In that case, such an occurrence could be characterized as stress-induced premature birth. Capture-induced parturition has already been described for the species (Wosnick et al. 2019). In previous observations, the mortality rate was $100 \%$ for embryos at different stages of development (Wosnick et al. 2019). However, it is possible that in this specific case the neonates have survived due to the size expected to be born in the species $(\sim 140 \mathrm{~mm} \mathrm{TL})$, making them fit to survive
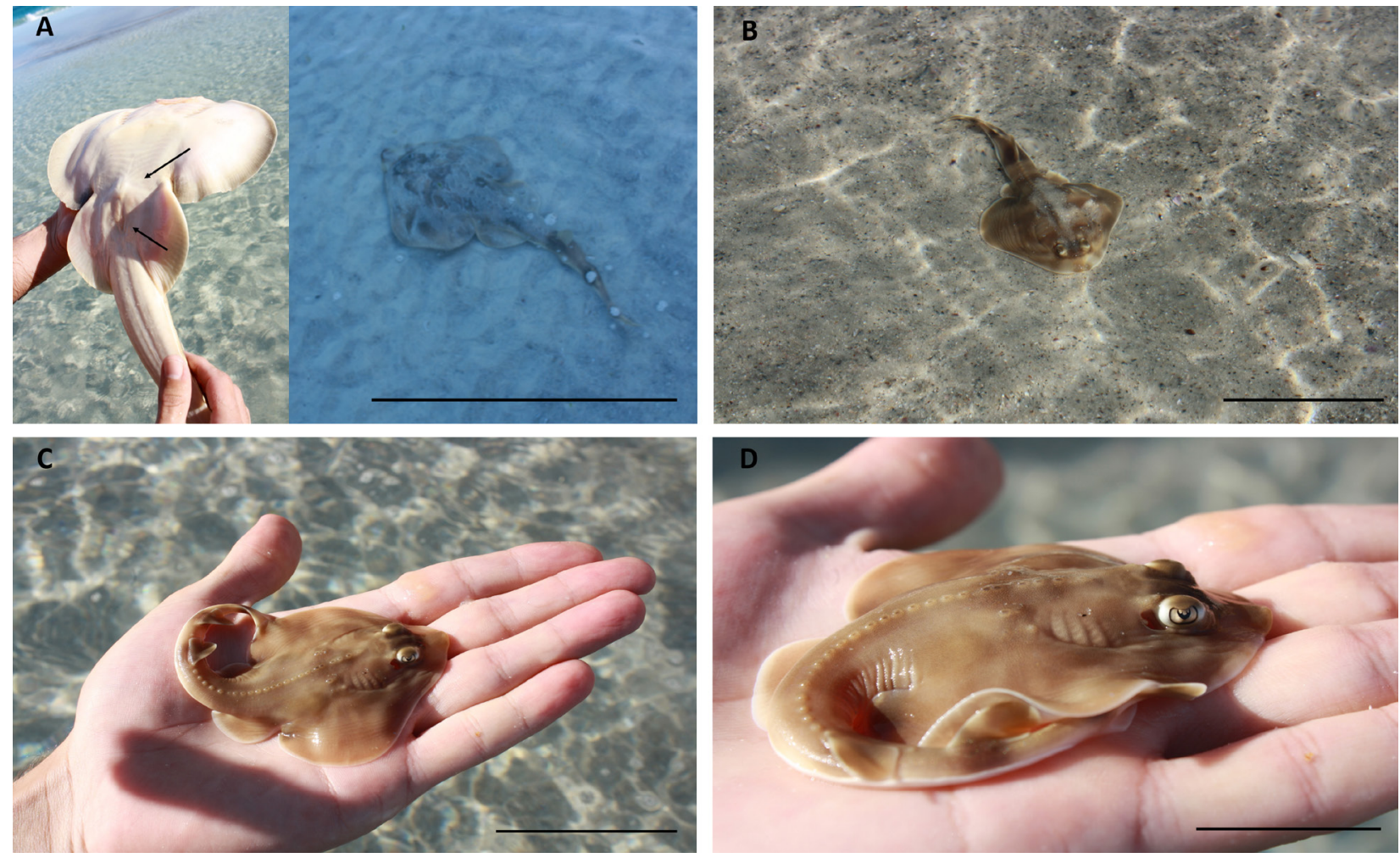

Fig. 2. Individuals of shortnose guitarfish, Zapteryx brevirostris, reported in this study; (A) female with signs of parturition, indicated by black arrows (contusions in the cloaca and abdominal retraction), scale bar $45 \mathrm{~cm}$; (B) staystill neonate, laying on the substrate, scale bar $10 \mathrm{~cm}$; (C) hand-captured neonate for size estimation, scale bar $7 \mathrm{~cm}$; (D) another neonate observed in the tide pool during period of isolation, scale bar $3 \mathrm{~cm}$ 
outside the maternal uterus. So, future studies should be focused on examining (1) whether tide pool use is common or only incidental for the species, (2) if it may occur in other elasmobranchs with high physiological plasticity and (3) if this phenomenon is, in fact, an advantageous use of the environment or only an effect of confinement stress and exposure to abiotic challenges.

\section{ACKNOWLEDGEMENTS}

We would like to thank Luana C. Munster for the photos provided and Marcelo Vianna for the technical and scientific contribution. We carried out a purely observational work so ethical permission was not considered necessary.

\section{REFERENCES}

Abilhoa V., Bornatowski H., Oliveira Freitas M. 2007. Some information on reproduction and embryonic development of the lesser guitarfish Zapteryx brevirostris in southern Brazil. Acta Adriatica 48 (2): 185-190.

Batista V.S. 1987. Desenvolvimento sexual de Zapteryx brevirostris (Müller et Henle, 1841), no litoral do Rio de Janeiro, Brasil. [Sexual development of Zapteryx brevirostris (Müller et Henle, 1841), on the coast of Rio de Janeiro, Brazil.] Revista Brasileira de Biologia 47 (3): 301-307. [In Portuguese.]

Batista V.S. 1991. Aspectos quantitativos da fecundidade e do desenvolvimento embrionário da raia Zapteryx brevirostris Müller et Henle, 1841 (Pisces, Rhinobatidae) da enseada de Itaipu, Niterói, Rio de Janeiro. [Quantitative aspects of the fecundity and embryonic development of the Zapteryx brevirostris Müller et Henle, 1841 (Pisces, Rhinobatidae) from the Itaipu cove, Niterói, Rio de Janeiro.] Revista Brasileira de Biologia 51 (3): 495-501. [In Portuguese.]

Bornatowski H., Wosnick N., do Carmo W.P.D. Corrêa, M.F.M. Abilhoa V. 2014. Feeding comparisons of four batoids (Elasmobranchii) in coastal waters of southern Brazil. Journal of the Marine Biological Association of the United Kingdom 94 (7): 1491-1499. DOI: $10.1017 / \mathrm{S} 0025315414000472$

Carmo W.P.D., Fávaro L.F., Coelho R. 2018. Age and growth of Zapteryx brevirostris (Elasmobranchii: Rhinobatidae) in southern Brazil. Neotropical Ichthyology 16 (1): e170005. DOI: 10.1590/19820224-20170005

Carvalho W.F., Gonzalez Rodriguez E. 2004. Development of primary and bacterial productivity in upwelling waters of Arraial do Cabo region, RJ (Brazil). Brazilian Journal of Oceanography 55 (1): 35-45. DOI: 10.1590/S1679-87592004000100004

Castellanos-Galindo G.A., Giraldo A. 2008. Food resource use in a tropical eastern Pacific tidepool fish assemblage. Marine Biology 153 (6): 1023-1035. DOI: 10.1007/s00227-007-0874-y

Coelho G.K.F., Nogueira L.A., Brito P.S., Piorski N.M., Nunes J.L.S. 2013. Use of tide pools as spawning site by the bocon toadfish Amphichthys cryptocentrus
(Batrachoidiformes: Batrachoididae), state of Maranhão, Brazil. Cybium 37 (3): 227-228.

Colonello J.C., García M.L., Menni R.C. 2011. Reproductive biology of the lesser guitarfish Zapteryx brevirostris from the South-western Atlantic Ocean. Journal of Fish Biology 78 (1): 287-302. DOI: 10.1111/j.1095-8649.2010.02864.x

Cunha F.A.C., Monteiro-Neto C., Nottingham M.C. 2007. Temporal and spatial variations in tidepool fish assemblages of the northeast coast of Brazil. Biota Neotropica 7 (1): 95-102. DOI: 10.1590/S167606032007000100016

Gonzalez M.M.B. 2004. Nascimento da Raiaviola, Zapteryx brevirostris (Müller et Henle) (Chondrichthyes, Rhinobatidae), em cativeiro. [Birth of guitarfish, Zapteryx brevirostris (Müller et Henle) (Chondrichthyes, Rhinobatidae) in captivity.] Revista Brasileira de Zoologia 21 (4): 785-788. [In Portuguese.] DOI: $10.1590 / \mathrm{S} 0101-81752004000400010$

Gonzalez-Rodriguez E., Valentin J.L., André D.L., Jacob S.A. 1992. Upwelling and downwelling at Cabo Frio (Brazil): Comparison of biomass and primary production responses. Journal of Plankton Research 14 (2): 289-306. DOI: 10.1093/plankt/14.2.289

Griffiths S.P., Davis A.R., West R.J. 2006. Role of habitat complexity in structuring temperate rockpool ichthyofaunas. Marine Ecology Progress Series 313: 227-239. DOI: 10.3354/meps313227

Guimaraes M.A., Coutinho R. 1995. Spatial and temporal variation of benthic marine algae at the Cabo Frio upwelling region, Rio de Janeiro, Brazil. Aquatic Botany 52 (4): 283-299. DOI: 10.1016/03043770(95)00511-0

Last P., White W., de Carvalho M., Séret B., Stehmann M., Naylor G. (eds.) 2016. Rays of the World. CSIRO Publishing, Melbourne, VIC, Australia.

Metaxas A., Scheibling R.E. 1993. Community structure and organization of tidepools. Marine Ecology Progress Series 98: 187-198. DOI: 10.3354/meps098187

Monteiro-Neto C., Tubino R.A., Moraes L.E.S., Mendonça Neto J.P., Esteves G.V., Fortes W.L. 2008. Associações de peixes na região costeira de Itaipu, Niterói, RJ. [Fish associations in the coastal region of Itaipu, Niterói.] Iheringia, Série Zoologica, 98 (1): 50-59. [In Portuguese.] DOI: 10.1590/S007347212008000100007

Nunes J.L.S., Pascoal N.G.D.A., Piorski N.M. 2011. Peixes intertidais do Maranhão [Intertidal fish from Maranhão]. Pp. 105-139. In: Nunes J.L.S., Piorski N.M. (eds.) Peixes marinhos e estuarinos do Maranhão. [Marine and estuarine fish from Maranhão.] Café \& Lápis, Brazil. [In Portuguese.]

Pierce S.J., Scott-Holland T.B., Bennett M.B. 2011. Community composition of elasmobranch fishes utilizing intertidal sand flats in Moreton Bay, Queensland, Australia. Pacific Science 65 (2): 235247. DOI: $10.2984 / 65.2 .235$

Tobin A.J., Mapleston A., Harry A.V., Espinoza M. 2014. Big fish in shallow water; use of an intertidal surf-zone 
habitat by large-bodied teleosts and elasmobranchs in tropical northern Australia. Environmental Biology of Fishes 97 (7): 821-838. DOI: 10.1007/s10641-0130182-y

Valentin J.L., Moteiro-Ribas W.M. 1993. Zooplankton community structure on the east-southeast Brazilian continental shelf $\left(18-23^{\circ} \mathrm{S}\right.$ latitude). Continental Shelf Research 13 (4): 407-427. DOI: 10.1016/02784343(93)90058-6

Vooren C.M., Klippel S. (eds.) 2005. Ações para a conservação de tubarões e raias no sul do Brasil. [Actions for the conservation of sharks and rays in southern Brazil.] Igaré, Porto Alegre, Brazil. [In Portuguese.]

Vooren C.M., Lessa R.P., Klippel S. 2005. Biologia e status de conservação da viola Rhinobatos horkelii [Biology and conservation status of the guitarfish Rhinobatos horkelii]. Pp. 33-56. In: Vooren C.M., Klippel S. (eds.) Ações para a conservação de tubarões e raias no sul do Brasil. [Actions for the conservation of sharks and rays in southern Brazil.] Igaré, Porto Alegre, Brazil. [In Portuguese.]

Wosnick N., Freire C.A. 2013. Some euryhalinity may be more common than expected in marine elasmobranchs: The example of the South American skate Zapteryx brevirostris (Elasmobranchii, Rajiformes, Rhinobatidae). Comparative Biochemistry and Physiology (A) Molecular and Integrative Physiology 166 (1): 36-43. DOI: 10.1016/j.cbpa.2013.05.002

Wosnick N., Adams K.R., Freire C.A. 2018. Ultrasonography as a promising methodology to indicate captured-induced abortion in viviparous elasmobranchs. Journal of Fish Biology 93 (6): 1033 1037. DOI: $10.1111 / \mathrm{jfb} .13746$

Wosnick N., Awruch C.A., Adams K.R., Gutierre S.M.M., Bornatowski H., Prado A.C., Freire C.A. 2019. Impacts of fisheries on elasmobranch reproduction: high rates of abortion and subsequent maternal mortality in the shortnose guitarfish. Animal Conservation 22 (2): 198-206. DOI: 10.1111/acv.12458

Received: 16 October 2018

Accepted: 13 November 2018

Published electronically: 15 June 2019 